\title{
Avaliação Microbiológica de logurte de Erva Doce
}

\author{
Karoline Griebler Ribeiro (I), Débora Machado Lopes (I), Gilson \\ Parussolo (I), Pablo Teixeira da Silva (I), Ana Eucares Von Laer (I) \\ (I) UFSM - Universidade Federal de Santa Maria (Linha Sete de Setembro, s/n, CEP: 98400 - \\ 000, Frederico Westphalen - RS)
}

\section{Resumo}

Iogurte, obtido através da fermentação por bactérias selecionadas (Streptococcus salivarius subsp. thermophilus e Lactobacillus delbrueckii subsp. Bulgaricus), é um produto de elevado valor nutritivo e qualidade sensorial, podendo ser adicionado de outras substâncias alimentícias que podem alterar suas características. A erva doce é uma planta que possui propriedades medicinais que contribuem para o bom funcionando do aparelho digestório e respiratório e, quando adicionada ao iogurte, pode causar melhorias ao produto. O objetivo do presente trabalho foi avaliar a qualidade microbiológica do iogurte adicionado de erva doce, para posterior avaliação da aceitabilidade e das características nutricionais do mesmo. Para elaboração do iogurte foi utilizado leite pasteurizado adicionado da cultura lática, que após a homogeneização foi incubado a $42^{\circ} \mathrm{C}$ por cerca de 4 horas para ocorrer a fermentação e formação do coágulo. $\mathrm{O}$ iogurte foi então, armazenado em câmara fria por aproximadamente 12 horas para acréscimo do preparado de erva doce. $\mathrm{O}$ concentrado da erva doce foi preparado por processo de infusão, para manter as propriedades medicinais, e adicionado ao iogurte nas concentrações de $15 \%, 25 \%$ e $35 \%$. A partir do iogurte adicionado de erva doce foram realizadas as análises microbiológicas de Staphylococcus coagulase positiva, Salmonella spp., bolores e leveduras e coliformes totais e termotolerantes, para uma avaliação da qualidade microbiológica geral, principalmente, em virtude da adição de erva doce e maior manipulação durante o processamento. Foi evidenciada ausência de Salmonella, 
contagem de Staphylococcus $>10$ UFC x g-1 e enumeração de coliformes totais e termotolerantes $>3$ NMP x g-1, resultados que salientam a segurança do produto em todas as concentrações avaliadas. Entretanto, a contagem de bolores e leveduras apresentou resultado entre $2 \times 10^{2}$ e 6 x $10^{2}$ UFC x g-1, acima do limite estabelecido no padrão de identidade e qualidade para leites fermentados. Provavelmente, essa contaminação teve origem na própria erva doce ou na manipulação imprópria do produto. Portanto, é necessário o desenvolvimento de um método mais adequado para obtenção do concentrado de erva doce, assim como um maior cuidado no processamento para que nas próximas etapas da pesquisa o iogurte apresente-se próprio para o consumo e viável para realizar a avaliação sensorial.

Palavras-Chave: Microbiologia, padrão de identidade e qualidade, produtos lácteos

\section{Agência de Fomento:}

